The $2{ }^{\text {nd }}$ Conf. of SSFOP "Future of Ornamental Plants in Egypt and Arab World", Cairo, Egypt, 21/2/2016

Scientific J. Flowers \& Ornamental Plants

www.ssfop.com/journal

ISSN: 2356-7864

\title{
RESPONSE OF MORINGA OLEIFERA TO ORGANIC BIOFERTILIZERS AND MINERAL NPK FERTILIZATIONS
}

\author{
M.A.H. Abdou*, A.A. El-Sayed ${ }^{*}$, R.A. Taha ${ }^{*}$ and S.E.A. Mosaad ${ }^{* *}$ \\ * Hort. Dept., Fac. Agric., Minia Univ., Egypt. \\ ** Fac. Agric., Aswan Univ., Egypt.
}

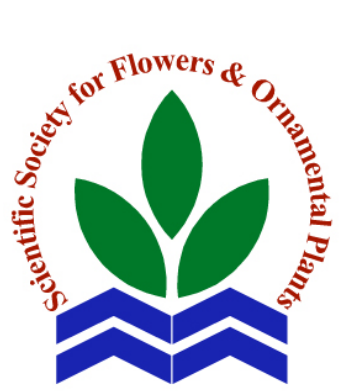

Scientific J. Flowers \& Ornamental Plants, 3(1):19-29 (2016).

Received:

21/1/2016

Revised by:

Prof. Dr. A.E. Awad, Zagazig Univ., Egypt.

Prof. Dr. A.Z. Sarhan, Cairo Univ.
ABSTRACT: This investigation was conducted to investigate the response of Moringa oleifera to compost fertilization at four levels ( 0 , 5, 10 and 15 ton/fed) and bio. and/or mineral NPK treatments [(control, 100\% NPK, 75\% NPK + phosphorein + Minia Azotein, 50\% NPK + phosphorein + Minia Azotein and phosphorein + Minia Azotein (Bio)] on vegetative growth traits, yield and pigments.

The obtained results indicate that, plant height, stem diameter, number of branches, number of pods/plant, number of seeds/pod and seed yield/plant, as well as, pigments were gradually increased by increasing the levels of compost fertilizer. All bio. and/or mineral NPK fertilization treatments significantly increased all the previous parameters. Bio. $+75 \%$ NPK dose followed by mineral NPK (full dose) treatments were more effective in this concern.

The highest values for vegetative growth traits, yield and yield components and pigments were obtained due to compost at 15 ton/fed in combination with bio. $+75 \%$ NPK dose.

Key words: Moringa oleifera, compost, fertilization, NPK, biofertilization, phosphorein, Minia Azotein, vegetative growth.

\section{INTRODUCTION}

Moringa oleifera is a fast growing tree which belongs to the moringaceae family. It is one of the most importance traditional multipurpose food plants that is produced and used in many African countries (Amaglo, 2007). Moringa has a great potential to become one of the most economically important crops for the tropics and subtropics considering its use in many fields as a medicine (Peixoto et al., 2011), food (Pontual et al., 2012) and fodder plant. The demand for the plant products has been on ascendancy. However, not much work has been done on its cultivation especially in the different ecological zones
Organic materials are added to soils to improve their physical and chemical properties of macro and micro elements, amino acids, organic acids, sugars and organic matter (Abo El-Fadl et al., 1968). Also, they considered useful substrate for several beneficial microorganisms and holding capacity. Dash and Gupta (2009), Imoro et al. (2012), Pahla et al. (2013) and Umar (2014) on Moringa oleifera found that organic manures treatment led to an increase in vegetative growth and pigments content in the fresh leaves of moringa.

Biofertilizers are considered to be low costs, ecofriendly and renewable sources of plant nutrients than supplementing chemical fertilizers in sustainable agricultural systems. Dash and Gupta (2009) and Asaolu et al. 
(2012) on Moringa oleifera concluded that biofertilizers treatments significantly increased plant height, stem diameter and fresh and dry biomass, as well as, pigments compared to control. Similar results were reported by Ravikumar et al. (2011) and ElQuesni et al. (2013) on Jatropha curcas, Abdou and Ashour (2012) on jojoba seedlings and Abdou et al. (2014) on Populus nigra.

Many authors studied the effects of mineral NPK fertilization on Moringa oleifera as Fagbenro et al. (2013); Abdullahi et al. (2013) and Umar (2014) who found that supplying plant with NPK (15:15:15) increased plant height, stem diameter, leaf production and fresh and dry biomass as compared with non fertilizer (control). Amin (2013) on Pinus radiata and Robinia pseudoacacia transplants concluded that mineral NPK fertilizers increased plant height, root length, stem diameter and fresh and dry weights of shoots and roots, as well as, chlorophyll a, b and carotenoids contents in the two plants under investigation.

Moringa can grow well under tropical and subtropical areas; however, fertilization needs to be investigated under the Egyptian conditions. This work aimed to investigate the response of Moringa oleifera to organic and bio-mineral fertilization in order to enhance and improve their characteristics.

\section{MATERIALS AND METHODS}

This investigation was carried out during the two successive seasons of 2013/2014 and 2014/2015 at the Nursery of Ornamental Plants, Faculty of Agricultural, Mina University to figure out the response of Moringa oleifera to organic and bio. and/or mineral fertilization treatments.

The seeds of Moringa oleifera were obtained from the Research Center of Medicinal and Aromatic Plant Section, Giza (Egypt) and were sown, in an unheated glasshouse, on January, $27^{\text {th }}$ for the two experimental seasons in $15 \mathrm{~cm}$ diameter pots filled with clay/sand soil $(1: 1 \mathrm{v} / \mathrm{v})$. Plants were transplanted in the experimental field on the first day of March in both seasons. Plants were thinned twice after one and two weeks from transplanting and left one plant/hill.

The experiment was arranged in a randomized complete block design in a split plot design with three replicates. The main plot (A) included for levels of compost $(0,5$, 10 and 15 ton/fed), while, the sub plot (B) included five treatments (control, 100\% NPK, 75\% NPK + Minia Azotein + phosphorein, 50\% NPK + Minia Azotein + phosphorein and Minia Azotein + phosphorein). Therefore, the interaction treatments $(\mathrm{A} \times \mathrm{B})$ were 20 treatments. The experimental unit (plot) was $4 \times 10 \mathrm{~m}$ and each contained 4 rows, $1 \mathrm{~m}$ apart. The seedlings were cultivated in hills, $1 \mathrm{~m}$ apart, therefore, each plot contained 40 plants. The physical and chemical analysis of the used soil in both seasons are determined according to Jackson (1973) and shown in Table (a).

The used compost (called compost ElNeel) was obtained from the Egyptian Co. for Solid Waste Utilization, New Minia city. Compost was added during preparing the soil to cultivation in the two seasons. Physical and chemical properties of the used compost are shown in Table (b).

Mineral NPK was used as $200 \mathrm{~kg}$ ammonium nitrate $(33.5 \% \quad \mathrm{~N}), 150 \mathrm{~kg}$ calcium superphosphate $\left(15.5 \% \mathrm{P}_{2} \mathrm{O}_{5}\right)$ and $75 \mathrm{~kg}$ potassium sulphate $\left(48 \% \mathrm{~K}_{2} \mathrm{O}\right) /$ fed for the treatment of $100 \%$ NPK. While, $75 \%$ NPK was represented by 150, 112.5 and 56.2 $\mathrm{kg} / \mathrm{fed}$. Also, 50\% mineral NPK was 100, 75 and $37.5 \mathrm{~kg} /$ fed of the above mentioned three fertilizers, respectively.

The amounts of NK were divided to three equal batches and added after 3 weeks from transplanting of seedlings and one month thereafter. All amounts of $\mathrm{P}$ were added during preparing the soil to cultivation for each season.

Fresh and active biofertilizers, Minia Azotein (M.A.) (containing N-fixing bacteria) and phosphorein (phos.) 
Table a. The physical and chemical analysis of the used soil.

\begin{tabular}{|c|c|c|c|}
\hline Soil Character & Value & Soil Character & Value \\
\hline Sand \% & 28.30 & Available P \% & 15.12 \\
\hline Silt \% & 30.70 & Exch. $\mathrm{K}^{+}$(mg/100 g soil) & 2.11 \\
\hline Clay \% & 41.00 & Exch. $\mathrm{Ca}^{++}(\mathrm{mg} / 100 \mathrm{~g}$ soil $)$ & 31.74 \\
\hline Soil type & Clayey loam & Exch. $\mathrm{Na}^{+}$(mg/100 g soil) & 2.41 \\
\hline Organic matter \% & 1.62 & \multirow{5}{*}{$\begin{array}{l}\text { DTPA } \\
\text { Ext. ppm }\end{array}$} & 8.54 \\
\hline $\mathrm{CaCO}_{3} \%$ & 2.09 & & 2.06 \\
\hline pH (1:2.5) & 7.83 & & 2.75 \\
\hline E.C. $(\mathbf{m m h o s} / \mathbf{c m})$ & 1.04 & & 8.26 \\
\hline Total N \% & 0.08 & & \\
\hline
\end{tabular}

Table b. Physical and chemical properties of the used compost.

\begin{tabular}{lclc}
\hline Properties & Values & Properties & Values \\
\hline Dry weight of $\mathbf{1} \mathbf{~ m}^{\mathbf{3}}$ & $450 \mathrm{~kg}$ & $\mathbf{C} / \mathbf{N}$ ratio & $14.1-18.5$ \\
Fresh weight of $\mathbf{1} \mathbf{~ m}^{\mathbf{3}}$ & $650-700 \mathrm{~kg}$ & $\mathbf{N a C l} \mathbf{( \% )}$ & $1.1-1.75$ \\
Moisture (\%) & $25-30$ & Total P (\%) & $0.5-0.75$ \\
pH (1:10) & $7.5-8$ & Total K (\%) & $0.8-1.0$ \\
E.C. (m mhose/cm) & $2-4$ & $\mathbf{F e ~ ( p p m ) ~}$ & $150-200$ \\
Total N \% & $1-1.4$ & $\mathbf{M n ~ ( p p m )}$ & 25.56 \\
Organic matter \% & $32-34$ & $\mathbf{C u}(\mathbf{p p m})$ & $75-150$ \\
Organic carbon \% & $18.5-19.7$ & $\mathbf{Z n}(\mathbf{p p m})$ & $150-225$ \\
\hline
\end{tabular}

(containing phosphate dissolving bacteria) were obtained from the Laboratory of Biofertilizers, Department of Genetic, Fac. of Agric., Minia Univ. Biofertilizers were applied three times to the soil beside the plants at the rate of $50 \mathrm{~cm}^{3} / \mathrm{hill}\left(1 \mathrm{ml} 10^{7}\right.$ cells of bacteria). The first dose, for both M.A. and phos. was added 4 weeks from transplanting date and reported 4 weeks thereafter. All other agricultural practices were performed as usual.

\section{Data recorded:}

\section{1- Vegetative growth parameters:}

The following data were recorded on the first week of November in both seasons: plant height (cm), number of branches/plant, stem diameter $(\mathrm{cm})$, leaves fresh weight/plant $(\mathrm{kg})$ and leaves dry weight per plant (g).

\section{2-Yield and yield components:}

All characters were recorded and calculated in first week of April (2014 and 2015) for each season: number of pods/plant, number of seeds/pod and seed weight/plant (g).

\section{3- Photosynthetic pigments:}

The three pigments namely, chlorophyll $\mathrm{a}, \mathrm{b}$ and carotenoids were determined in the fresh leaves at the middle of branches, during the July, $21^{\text {st }}$ in the two seasons 2014 and $2015 \mathrm{as} \mathrm{mg/g} \mathrm{f.w.} \mathrm{according} \mathrm{to} \mathrm{Moran}$ (1982).

Statistical analysis: all data were tabulated and statistically analyzed according 
to MSTAT-C (1986) and the L.S.D. test at $5 \%$ was followed to compared between the means.

\section{RESULTS AND DISCUSSION}

\section{1-Vegetative growth characters:}

Data presented in Tables (1 and 2) show that plant height, stem diameter, number of branches/plant and leaves fresh and dry weights/plant were significantly increased in both seasons due to the use of compost at 5 , 10 and 15 ton/fed in comparison with those of control. The increase was gradual by the gradual increase in compost fertilizer levels. The increase in vegetative growth traits due to low, medium and high level of compost over the control reached 9.87, 15.45 and $23.18 \%$ for plant height, 6.38, 13.15 and $20.50 \%$ for stem diameter, $17.04,34.07$ and $46.90 \%$ for number of branches, 10.37, 15.66 and $23.48 \%$ for leaves fresh weight/plant and 10.21, 15.44 and $23.17 \%$ for leaves dry weight/plant, respectively, in the first season. The results in the second season took similar trend. Similar results were found by Dash and Gupta (2009), Imoro et al. (2012), Pahla et al. (2013) and Umar (2014) on moringa.

Data presented in Tables (1 and 2) indicate that plant height, stem diameter, number of branches/plant, fresh and dry weights/plant were significantly increased, in both seasons, due to the used of all treatments of bio. and/or mineral NPK fertilization in comparison with unfertilized control. The treatments of mixture biofertilizers (phosphorein + Minia Azotein) $+75 \%$ NPK dose followed by mineral NPK (100\%) seemed to be more effective than other two treatments. However, significant differences were detected between such two superior treatments for the five vegetative growth characters in the two seasons. These findings go parallel with those of Dash and Gupta (2009) and Asaolu et al. (2012) on moringa; Ravikumar et al. (2011) on Jatropha curcas and Abdou and Ashour (2012) on jojoba regarding the effect of biofertilizers, meantime, Fagbenro et al.
(2013); Abdullahi et al. (2013) and Umar (2014) on moringa, found that NPK treatments increased plant height, stem diameter and fresh and dry biomass.

The interaction between compost and bio. and/or mineral NPK fertilization treatments was significant, in the two seasons for the five characters. The highest values were obtained due to supplying Moringa oleifera with compost at 15 ton/fed in combination with bio. $+75 \%$ NPK dose or mineral NPK (100\%).

\section{2-Yield and yield components:}

Data presented in Table (3) during both seasons reveal that the used of compost treatments has pronounced significant effects on number of pods/plant, number of seeds/pod and yield of seeds/plant when compared with untreated ones in the two growing seasons. The highest values of the three parameters resulted from the treatment of 15 ton/fed followed by 10 ton/fed then 5 ton/fed of compost. Similar, results were obtained by Ugbaja (1996) on castor oil, Kayina et al. (2012) on senna and Dahmardeh (2012) on roselle plants.

The stimulatory effect of compost treatments on vegetative growth traits and yield of plant may be due to organic manure which gave availability of most nutrients, such stimulation on the uptake of nutrients leads to enhancing the biosynthesis of organic foods and cell division, more carbohydrates and dry matter accumulation (Nijjar, 1985).

Data in Table (3) show that all used fertilization treatments significantly increased in number of pods/plant, number of seeds/pod and seed yield/plant over the control in both seasons. The highest values of number of pods/plant, number of seeds/pod and seed yield/plant were resulted from the treatments of bio. $+75 \%$ NPK dose.

The stimulatory effect of biofertilizers and/or mineral NPK may be attributed to the role of NPK on plant physiological processes (Devlin, 1975), also, biofertilizers increase soil available $\mathrm{N}$ and $\mathrm{P}$, as well as, other 
Table 1. Effect of compost, NPK and biofertilization treatments on plant height $(\mathrm{cm})$, stem diameter $(\mathrm{cm})$ and number of branches/plant of moringa (Moringa oleifera, L.) plants, during 2013/2014 and 2014/2015 seasons.

\begin{tabular}{|c|c|c|c|c|c|c|c|c|c|c|}
\hline \multirow{3}{*}{$\begin{array}{c}\text { NPK and } \\
\text { biofertilization } \\
\text { treatments (B) }\end{array}$} & \multicolumn{10}{|c|}{ Compost levels (ton/fed) (A) } \\
\hline & \multirow[b]{2}{*}{$\mathbf{0}$} & \multicolumn{3}{|c|}{$1^{\text {st }}$ season } & \multirow{2}{*}{$\begin{array}{c}\text { Mean } \\
\text { (B) }\end{array}$} & \multicolumn{4}{|c|}{$2^{\text {nd }}$ season } & \multirow[b]{2}{*}{$\begin{array}{c}\text { Mean } \\
\text { (B) }\end{array}$} \\
\hline & & 5 & 10 & 15 & & $\mathbf{0}$ & 5 & 10 & 15 & \\
\hline \multicolumn{11}{|c|}{ Plant height (cm) } \\
\hline Control & 180 & 196 & 204 & 217 & 199 & 198 & 216 & 245 & 260 & 230 \\
\hline $100 \%$ NPK & 250 & 275 & 290 & 309 & 281 & 275 & 303 & 348 & 371 & 324 \\
\hline Bio. + 75\% NPK & 268 & 297 & 311 & 334 & 303 & 295 & 327 & 373 & 401 & 349 \\
\hline Bio. + 50\% NPK & 245 & 272 & 285 & 306 & 277 & 270 & 299 & 342 & 367 & 320 \\
\hline Bio. & 220 & 242 & 253 & 269 & 246 & 242 & 266 & 304 & 323 & 284 \\
\hline Mean (A) & 233 & 256 & 269 & 287 & & 256 & 282 & 322 & 344 & \\
\hline L.S.D. at $5 \%$ & \multicolumn{2}{|c|}{ A: 8.68} & B: 11.27 & \multicolumn{2}{|c|}{$\mathrm{AB}: 22.55$} & \multicolumn{2}{|c|}{ A: 9.98} & B: 12.96 & \multicolumn{2}{|c|}{ AB: 25.92} \\
\hline \multicolumn{11}{|c|}{ Stem diameter $(\mathrm{cm})$} \\
\hline Control & 4.38 & 4.69 & 4.98 & 5.28 & 4.83 & 5.69 & 6.11 & 647 & 6.86 & 6.28 \\
\hline $100 \%$ NPK & 5.06 & 5.45 & 5.86 & 6.31 & 5.67 & 7.08 & 7.63 & 8.20 & 8.83 & 7.94 \\
\hline Bio. + 75\% NPK & 6.40 & 6.79 & 7.21 & 7.68 & 7.02 & 8.96 & 9.51 & 10.09 & 10.75 & 9.83 \\
\hline Bio. + 50\% NPK & 5.03 & 5.31 & 5.66 & 5.99 & 5.50 & 7.04 & 7.43 & 7.92 & 8.39 & 7.70 \\
\hline Bio. & 4.98 & 5.26 & 5.56 & 5.89 & 5.42 & 6.97 & 7.28 & 7.78 & 8.25 & 7.57 \\
\hline Mean (A) & 5.17 & 5.50 & 5.85 & 6.23 & & 7.15 & 7.59 & 8.09 & 8.62 & \\
\hline L.S.D. at $5 \%$ & \multicolumn{2}{|c|}{ A: 0.11} & B: 0.13 & \multicolumn{2}{|c|}{ AB: 0.26} & \multicolumn{2}{|c|}{ A: 0.15} & B: 0.18 & \multicolumn{2}{|c|}{ AB: 0.36} \\
\hline \multicolumn{11}{|c|}{ Number of branches/plant } \\
\hline Control & 4.03 & 4.73 & 5.53 & 6.17 & 5.12 & 4.19 & 4.92 & 5.75 & 6.42 & 5.32 \\
\hline $100 \%$ NPK & 4.73 & 5.53 & 6.23 & 6.77 & 5.82 & 4.97 & 5.81 & 6.54 & 7.11 & 6.11 \\
\hline Bio. + 75\% NPK & 4.90 & 5.83 & 6.37 & 7.10 & 6.05 & 5.15 & 6.12 & 6.69 & 7.46 & 6.36 \\
\hline Bio. + 50\% NPK & 4.53 & 5.27 & 6.17 & 6.67 & 5.66 & 4.76 & 5.53 & 6.48 & 7.00 & 5.94 \\
\hline Bio. & 4.40 & 5.10 & 6.00 & 6.50 & 5.50 & 4.62 & 5.36 & 6.30 & 6.83 & 5.78 \\
\hline Mean (A) & 4.52 & 5.29 & 6.06 & 6.64 & & 4.74 & 5.55 & 6.35 & 6.96 & \\
\hline L.S.D. at $5 \%$ & \multicolumn{2}{|c|}{ A: 0.36} & B: 0.22 & \multicolumn{2}{|c|}{ AB: N.S. } & \multicolumn{2}{|c|}{ A: 0.38} & B: 0.23 & \multicolumn{2}{|c|}{ AB: 0.46} \\
\hline
\end{tabular}

Bio. $=$ Phosphorein + Minia Azotein 
Table 2. Effect of compost, NPK and biofertilization treatments on leaves fresh weight/plant (kg) and leaves dry weight/plant (g) of moringa (Moringa oleifera, L.) plants, during 2013/2014 and 2014/2015 seasons.

\begin{tabular}{|c|c|c|c|c|c|c|c|c|c|c|}
\hline \multirow{3}{*}{$\begin{array}{c}\text { NPK and } \\
\text { biofertilization } \\
\text { treatments (B) }\end{array}$} & \multirow{2}{*}{\multicolumn{10}{|c|}{ Compost levels (ton/fed) (A) }} \\
\hline & \multirow[b]{2}{*}{$\mathbf{0}$} & \multicolumn{2}{|c|}{$1^{\text {st }}$ season } & & & & & & & \\
\hline & & 5 & 10 & 15 & $\begin{array}{c}\text { Mean } \\
\text { (B) }\end{array}$ & $\mathbf{0}$ & 5 & 10 & 15 & $\begin{array}{c}\text { Mean } \\
\text { (B) }\end{array}$ \\
\hline \multicolumn{11}{|c|}{ Leaves fresh weight/plant (kg) } \\
\hline Control & 3.61 & 3.93 & 4.09 & 4.34 & 3.99 & 4.96 & 5.50 & 5.73 & 6.00 & 5.55 \\
\hline $100 \%$ NPK & 5.51 & 6.05 & 6.38 & 6.80 & 6.19 & 7.71 & 6.29 & 8.93 & 9.52 & 8.11 \\
\hline Bio. + 75\% NPK & 6.43 & 7.13 & 7.47 & 8.02 & 7.26 & 9.00 & 9.98 & 10.46 & 11.23 & 10.17 \\
\hline Bio. $+50 \%$ NPK & 5.39 & 5.99 & 6.28 & 6.74 & 6.10 & 7.50 & 8.39 & 8.79 & 9.44 & 8.53 \\
\hline Bio. & 4.62 & 5.09 & 5.32 & 5.64 & 5.17 & 6.40 & 7.13 & 7.45 & 7.90 & 7.22 \\
\hline Mean (A) & 5.11 & 5.64 & 5.91 & 6.31 & & 7.11 & 7.46 & 8.27 & 8.82 & \\
\hline L.S.D. at $5 \%$ & \multicolumn{2}{|c|}{ A: 0.15} & B: 0.24 & \multicolumn{2}{|c|}{ AB: 0.49} & \multicolumn{2}{|c|}{ A: 0.21} & B: 0.34 & \multicolumn{2}{|c|}{ AB: 0.68} \\
\hline \multicolumn{11}{|c|}{ Leaves dry weight/plant (g) } \\
\hline Control & 396.7 & 431.8 & 449.8 & 477.5 & 439.0 & 535.5 & 626.1 & 652.2 & 692.0 & 626.5 \\
\hline $100 \%$ NPK & 550.7 & 605.1 & 638.1 & 679.4 & 618.3 & 798.5 & 877.3 & 925.3 & 985.0 & 896.5 \\
\hline Bio. + 75\% NPK & 642.6 & 7.12 .2 & 744.9 & 798.8 & 724.6 & 931.8 & 1032.7 & 1080.1 & 1158.3 & 1050.7 \\
\hline Bio. + 50\% NPK & 538.5 & 597.2 & 626.7 & 672.8 & 608.8 & 780.0 & 865.9 & 908.7 & 975.6 & 882.6 \\
\hline Bio. & 462.5 & 509.0 & 531.6 & 562.8 & 516.5 & 670.6 & 738.1 & 770.8 & 816.1 & 748.9 \\
\hline Mean (A) & 518.2 & 571.1 & 598.2 & 638.3 & & 743.3 & 828.0 & 867.4 & 925.4 & \\
\hline L.S.D. at 5\% & \multicolumn{2}{|c|}{ A: 15.0} & B: 24.8 & \multicolumn{2}{|c|}{ AB: 49.6} & \multicolumn{2}{|c|}{ A: 21.8} & B: 36.0 & \multicolumn{2}{|c|}{ AB: 72.0} \\
\hline
\end{tabular}

nutrient elements, consequently increase formation of metabolites which encourage the plant vegetative growth and yield or gibberellin and auxins which as a result from inoculation of biofertilizers that encourage the cell division and cell enlargement that increase the biosynthesis and metabolites which consequently increased carbohydrates accumulation in the seeds (Spernat, 1990 and Hauka, 2000).

The interaction between main and sub plot treatments was significant for number of pods/plant, number of seeds/pod and seed weight/plant in both seasons. The highest number of pods/plant (32.73 and 39.28 in both seasons), number of seeds/pod (33.08 and 36.39 in both seasons) and heaviest weight of seeds/plant (148.01 and 205.12 $\mathrm{g}$ /plant in both seasons) were obtained by adding compost (15 ton/fed) in combination with bio. $+75 \%$ NPK dose as cleared shown in Table (3).

\section{3- Photosynthetic pigments:}

The contents of chlorophyll a, b and carotenoids were significantly promoted due to compost treatments, in the two seasons, in comparison with those of untreated plants as shown in Table (4). Compost at 15 ton/fed gave the highest values for chlorophyll a, b and carotenoids followed by compost (10 ton/fed) and then compost ( 5 ton/fed) in both seasons. These results may be attributed to the increase nutrient elements and/or positive role of $\mathrm{Mg}$ that reflect on the chlorophyll content.

In harmony with these results regarding organic fertilization treatments were reported by Abass (2003) on Rosa hybrida, Sakr (2005) on senna plants, El-Khateeb et al. (2006) and Abdou et al. (2007) on Ficus spp. 
Table 3. Effect of compost, NPK and biofertilization treatments on number of pods/plant, number of seeds/pod and seed weight/plant (g) of moringa (Moringa oleifera, L.) plants, during 2013/2014 and 2014/2015 seasons.

\begin{tabular}{|c|c|c|c|c|c|c|c|c|c|c|}
\hline \multirow{3}{*}{$\begin{array}{c}\text { NPK and } \\
\text { biofertilization } \\
\text { treatments (B) }\end{array}$} & \multicolumn{10}{|c|}{ Compost levels (ton/fed) (A) } \\
\hline & \multirow[b]{2}{*}{$\mathbf{0}$} & \multicolumn{3}{|c|}{$1^{\text {st }}$ season } & \multirow[b]{2}{*}{$\begin{array}{c}\text { Mean } \\
\text { (B) }\end{array}$} & \multicolumn{4}{|c|}{$2^{\text {nd }}$ season } & \multirow[b]{2}{*}{$\begin{array}{c}\text { Mean } \\
\text { (B) }\end{array}$} \\
\hline & & 5 & 10 & 15 & & $\mathbf{0}$ & 5 & 10 & 15 & \\
\hline \multicolumn{11}{|c|}{ Number of pods/plant } \\
\hline Control & 11.73 & 15.13 & 18.21 & 21.24 & 16.58 & 12.90 & 16.64 & 20.03 & 23.36 & 18.23 \\
\hline $100 \%$ NPK & 20.44 & 23.46 & 25.39 & 28.47 & 24.44 & 24.53 & 28.15 & 30.47 & 34.16 & 29.33 \\
\hline Bio. + 75\% NPK & 22.59 & 26.24 & 29.15 & 32.73 & 27.68 & 27.11 & 31.49 & 34.98 & 39.28 & 33.22 \\
\hline Bio. + 50\% NPK & 17.99 & 21.93 & 24.95 & 28.55 & 23.36 & 21.59 & 26.32 & 29.94 & 34.26 & 28.03 \\
\hline Bio. & 14.83 & 18.39 & 21.44 & 25.07 & 19.93 & 17.80 & 22.07 & 25.73 & 30.08 & 23.92 \\
\hline Mean (A) & 17.52 & 21.03 & 23.83 & 29.21 & & 20.79 & 24.93 & 28.23 & 32.23 & \\
\hline L.S.D. at 5\% & \multicolumn{2}{|c|}{ A: 0.55} & B: 0.46 & \multicolumn{2}{|c|}{ AB: 0.92} & \multicolumn{2}{|c|}{ A: 0.66} & B: 0.55 & \multicolumn{2}{|c|}{ AB: 1.10} \\
\hline \multicolumn{11}{|c|}{ Number of seeds/pod } \\
\hline Control & 20.74 & 22.10 & 23.46 & 25.26 & 22.89 & 21.81 & 24.31 & 25.81 & 27.79 & 24.93 \\
\hline $100 \%$ NPK & 24.82 & 26.52 & 28.56 & 30.70 & 27.65 & 27.30 & 29.17 & 31.42 & 33.77 & 30.42 \\
\hline Bio. + 75\% NPK & 25.84 & 28.22 & 29.22 & 33.08 & 29.27 & 28.42 & 31.04 & 32.14 & 36.39 & 32.00 \\
\hline Bio. + 50\% NPK & 23.46 & 25.16 & 26.86 & 29.00 & 26.12 & 25.81 & 27.68 & 29.55 & 31.90 & 28.74 \\
\hline Bio. & 22.44 & 24.14 & 25.50 & 27.64 & 24.93 & 24.68 & 26.55 & 28.05 & 30.40 & 27.42 \\
\hline Mean (A) & 23.46 & 25.23 & 26.72 & 29.14 & & 25.60 & 27.75 & 29.39 & 32.05 & \\
\hline L.S.D. at $5 \%$ & \multicolumn{2}{|c|}{ A: 0.60} & B: 0.99 & \multicolumn{2}{|c|}{$\mathrm{AB}: 1.98$} & \multicolumn{2}{|c|}{ A: 0.66} & B: 1.09 & \multicolumn{2}{|c|}{ AB: 2.18} \\
\hline \multicolumn{11}{|c|}{ Seed weight/plant (g) } \\
\hline Control & 24.89 & 36.95 & 47.63 & 63.10 & 43.14 & 30.22 & 46.92 & 60.54 & 80.17 & 54.46 \\
\hline $100 \%$ NPK & 57.43 & 76.03 & 89.49 & 113.71 & 84.17 & 79.62 & 105.35 & 124.08 & 157.58 & 116.66 \\
\hline Bio. + 75\% NPK & 69.41 & 94.19 & 110.39 & 148.01 & 105.50 & 96.23 & 130.59 & 153.01 & 205.12 & 146.24 \\
\hline Bio. + 50\% NPK & 46.85 & 64.94 & 81.09 & 105.65 & 74.63 & 64.97 & 90.05 & 112.45 & 146.45 & 103.48 \\
\hline Bio. & 36.61 & 51.76 & 65.55 & 87.66 & 60.40 & 50.30 & 71.72 & 90.87 & 121.44 & 83.58 \\
\hline Mean (A) & 47.04 & 64.77 & 78.83 & 103.63 & & 64.27 & 88.93 & 108.19 & 142.15 & \\
\hline L.S.D. at 5\% & \multicolumn{2}{|c|}{ A: 5.58} & B: 4.53 & \multicolumn{2}{|c|}{ AB: 9.06} & \multicolumn{2}{|c|}{ A: 6.15} & B: 4.98 & \multicolumn{2}{|c|}{ AB: 9.96} \\
\hline
\end{tabular}

Bio. $=$ Phosphorein + Minia Azotein 
Table 4. Effect of compost, NPK and biofertilization treatments on chlorophyll a, $b$ and carotenoids (mg/g f.w.) of moringa (Moringa oleifera, L.) plants, during 2013/2014 and 2014/2015 seasons.

\begin{tabular}{|c|c|c|c|c|c|c|c|c|c|c|}
\hline \multirow{3}{*}{$\begin{array}{c}\text { NPK and } \\
\text { biofertilization } \\
\text { treatments (B) }\end{array}$} & \multirow{2}{*}{\multicolumn{10}{|c|}{ Compost levels (ton/fed) (A) }} \\
\hline & \multirow[b]{2}{*}{$\mathbf{0}$} & \multicolumn{3}{|c|}{$1^{\text {st }}$ season } & \multirow[b]{2}{*}{$\begin{array}{l}\text { Mean } \\
\text { (B) }\end{array}$} & & & & & \multirow[b]{2}{*}{$\begin{array}{c}\text { Mean } \\
\text { (B) }\end{array}$} \\
\hline & & 5 & 10 & 15 & & $\mathbf{0}$ & 5 & 10 & 15 & \\
\hline \multicolumn{11}{|c|}{ Chlorophyll a (mg/g f.w.) } \\
\hline Control & 2.891 & 3.036 & 3.188 & 3.347 & 3.116 & 2.920 & 3.066 & 3.220 & 3.380 & 3.147 \\
\hline $100 \%$ NPK & 3.158 & 3.315 & 3.480 & 3.654 & 3.402 & 3.190 & 3.348 & 3.515 & 3.691 & 3.436 \\
\hline Bio. $+75 \%$ NPK & 3.189 & 3.349 & 3.516 & 3.692 & 3.437 & 3.221 & 3.382 & 3.551 & 3.729 & 3.471 \\
\hline Bio. + $50 \%$ NPK & 3.037 & 3.188 & 3.347 & 3.514 & 3.272 & 3.067 & 3.220 & 3.380 & 3.549 & 3.305 \\
\hline Bio. & 2.920 & 3.066 & 3.219 & 3.379 & 3.146 & 2.949 & 3.097 & 3.251 & 3.413 & 3.177 \\
\hline Mean (A) & 3.039 & 3.191 & 3.350 & 3.517 & & 3.069 & 3.223 & 3.384 & 3.552 & \\
\hline L.S.D. at $5 \%$ & \multicolumn{2}{|c|}{ A: 0.111} & B: 0.028 & \multicolumn{2}{|c|}{ AB: 0.056} & \multicolumn{2}{|c|}{ A: 0.116} & B: 0.031 & \multicolumn{2}{|c|}{ AB: 0.062} \\
\hline \multicolumn{11}{|c|}{ Chlorophyll b (mg/g f.w.) } \\
\hline Control & 0.934 & 0.982 & 1.033 & 1.085 & 1.009 & 0.943 & 0.992 & 1.043 & 1.096 & 1.019 \\
\hline $100 \%$ NPK & 1.032 & 1.105 & 1.130 & 1.188 & 1.114 & 1.042 & 1.116 & 1.141 & 1.200 & 1.125 \\
\hline Bio. + 75\% NPK & 1.033 & 1.116 & 1.170 & 1.231 & 1.138 & 1.043 & 1.127 & 1.182 & 1.243 & 1.149 \\
\hline Bio. + $50 \%$ NPK & 0.982 & 1.033 & 1.086 & 1.141 & 1.061 & 0.992 & 1.043 & 1.097 & 1.152 & 1.072 \\
\hline Bio. & 0.943 & 0.992 & 1.045 & 1.095 & 1.019 & 0.952 & 1.002 & 1.055 & 1.106 & 1.029 \\
\hline Mean (A) & 0.985 & 1.046 & 1.093 & 1.148 & & 0.995 & 1.056 & 1.104 & 1.159 & \\
\hline L.S.D. at $5 \%$ & \multicolumn{2}{|c|}{ A: 0.038} & B: 0.008 & \multicolumn{2}{|c|}{ AB: 0.016} & \multicolumn{2}{|c|}{ A: 0.040} & B: 0.012 & \multicolumn{2}{|c|}{ AB: 0.024} \\
\hline \multicolumn{11}{|c|}{ Carotenoids (mg/g f.w.) } \\
\hline Control & 0.993 & 1.041 & 1.092 & 1.146 & 1.068 & 1.003 & 1.051 & 1.103 & 1.157 & 1.079 \\
\hline $100 \%$ NPK & 1.112 & 1.165 & 1.191 & 1.248 & 1.179 & 1.123 & 1.177 & 1.203 & 1.260 & 1.191 \\
\hline Bio. + 75\% NPK & 1.121 & 1.172 & 1.232 & 1.291 & 1.204 & 1.132 & 1.184 & 1.244 & 1.304 & 1.216 \\
\hline Bio. + 50\% NPK & 1.042 & 1.092 & 1.146 & 1.201 & 1.120 & 1.052 & 1.103 & 1.157 & 1.213 & 1.131 \\
\hline Bio. & 1.003 & 1.052 & 1.103 & 1.156 & 1.079 & 1.013 & 1.063 & 1.114 & 1.168 & 1.090 \\
\hline Mean (A) & 1.054 & 1.104 & 1.153 & 1.208 & & 1.065 & 1.115 & 1.165 & 1.220 & \\
\hline L.S.D. at 5\% & \multicolumn{2}{|c|}{ A: 0.042} & B: 0.010 & \multicolumn{2}{|c|}{ AB: 0.020} & \multicolumn{2}{|c|}{ A: 0.045} & B: 0.009 & \multicolumn{2}{|c|}{ AB: 0.018} \\
\hline
\end{tabular}

Bio. $=$ Phosphorein + Minia Azotein 
In relation to the influence of different biofertilizers and/or mineral NPK treatments, chlorophyll a, b and carotenoids contents was promoted in the two seasons (Table, 4). Obtained data showed that fertilization treatment and control were statistically significant. The highest contents were obtained due to the treatment of bio. $+75 \%$ NPK dose. These results may be attributed to the increase in nutrient elements which came as a result from adding NPK or inoculated with bacteria that reflect on chlorophyll content. Similar results were obtained by Ashour (2010) on jojoba and Abdou et al. (2014) on Populus nigra.

The interaction between compost and bio. and/or mineral NPK fertilization treatments was significant, in both seasons, for chlorophyll a, b and carotenoids contents.

\section{REFERENCES}

Abass, R.A. (2003). Effect of the natural and synthetic soil conditioners on the growth of Rosa hybrida cv. Queen Elizabeth. J. Adv. Agric. Res., 8(4):673-688.

Abdou, M.A.H.; Ahmed, E.E.T.; Ahmed, A.A. and Abdel-Mola, M.A.M. (2014). Response of Populus nigra, l. seedlings to compost, biofertilizers and mineral NPK fertilization. Minia J. of Agric. Res. \& Develop., 34(1):31-47.

Abdou, M.A.H. and Ashour, R.M. (2012). Physiological studies on jojoba plants. Minia Inter. Conf. for Agric. and Irrig. In the Nile Basin countries. $26^{\text {th }}-29^{\text {th }}$ March 2012, El-Minia, Egypt.

Abdou, M.A.H.; Badran, F.S.; Aly, M.K. and Ashour, R.M. (2007). Physiological studies on the propagation of Ficus elastica var. Decora by aerial layering. $1^{\text {st }}$ Inter. Conf. Desert Cultivation, Problems \& Solutions, Minia Univ., 27-29 March, 2007.

Abdullahi, I.N.; Ochi, K. and Gwaram, A.B. (2013). Plant population and fertilizer application effects on biomass productivity of Moringa oleifera in North-Central Nigeria. Peak Journal of Agricultural Sciences, 1(6):94-100.

Abo El-Fadl, M.; Rizk, S.G. Abdel-Ghani, A.F.; El-Mofty, M.K.; Khadr, M.F.A.; Shehata, S.M. and Farag, F.A. (1968). Utilization of Water Hyacinth as an organic manure with special reference to water-borne helminthes. J. Microbial, ARE, 3(1):27-34.

Amaglo, N.K. (2007). Effect of Spacing and Harvest Frequency on The Growth and Leave Yield of Moringa oleifera, Lam., a Leafy Vegetable Crop. M.Sc. Thesis, Knust, Ghana.

Amin, M.A. (2013). Study of the fertigation requirement for some woody trees. J. Appl. Sci. Res., 9(1):284-293.

Asaolu, V.O.; Binuomote, R.; Akinlade, J.; Aderinola, O. and Oyelami, O. (2012). Intake and growth performance of West African Dwarf goats fed Moringa oleifera Gliricidia sepium and Leucaena leucocephala dried leaves as supplements to Cassava Peels. J. Biol. Agric. Health Care, 2(10):76-88.

Ashour, R.M. (2010). Response of Jojoba Plants to Some Organic and Biofertilization Treatments. Ph.D. Thesis, Fac. Agric., Minia Univ., Egypt.

Dahmardeh, M. (2012). Effect of mineral and organic fertilizers on the growth and calyx yield of roselle (Hibiscus sabdariffa, L.). Afr. J. Biotechnol., 11(48):10899-10902.

Dash, S. and Gupta, N. (2009). Effect of inorganic, organic and bio fertilizer on growth of hybrid Moringa oleifera $\left(\mathrm{PKM}_{1}\right)$. Academic Journal of Plant Sciences, 2(3):220-221.

Devlin, R.M. (1975). Plant Physiology. $3^{\text {rd }}$ Ed. Affiliated East West Press, New Delhi. Chap. 10, 11:159-205. 
El-Khateeb, M.A.; El-Madaawy, E.E. and El-Attar, A.B. (2006). Effect of growing media on growth and chemical composition of Ficus alii, plants. Ann. Agric. Sci., Moshtohor, 44(1):175-193.

El-Quesni, Fatma E.M.; Hashish, K.I.; Kandil, M.M. and Mazher, A.A.M. (2013). Impact of some biofertilizers and compost on growth and chemical composition of Jatropha curcas, L. World Appl. Sci. J., 21(6):927-932.

Fagbenro, J.A.; Oshunsanya, S.O. and Onawumi, O.A. (2013). Effect of saw dust biochar and NPK 15:15:15 inorganic fertilizer on Moringa oleifera seedlings grown in an oxisol. Agrosearch, 13(1):57-68.

Hauka, F.I.A. (2000). Impact of dual inoculation with Rhizobium sesbania and vesicular-arbuscular mycorrhiza on growth and nutrition of Sesbania aegyptiaca in a calcareous soil. J. Agric. Sci., Mansoura Univ., 25(10):6465-6480.

Imoro, A.W.M.; Sackey, I. and Abubakar, A.H. (2012). Preliminary study on the effects of two different sources of organic manure on the growth performance of Moringa oleifera seedlings. Journal of Biology, Agriculture and Healthcare, 2(10):147-158.

Jackson, M.L. (1973). Soil Chemical Analysis. Englewood Cliffs, New Prentice - Hall INC., New York.

Kayina, A.; Das, B. and Reddy, G.S. (2012). Effect of organic manures, biofertilizers and inorganic fertilizers on growth and yield of senna (Cassia angustifolia, Vahl.). The Asian Journal of Horticulture, 7(1):144-147.

Moran, R. (1982). Formula determination of chlorophylls pigment extracted with $\mathrm{N}$ N-dimethyl-formamide. Plant Physiol., 69:1376-1381.

MSTAT-C (1986). A Microcomputer Program for the Design, Management and Analysis of Agronomic Research
Experiments (Version 4.0), Michigan State Univ., U.S.

Nijjar, G.S. (1985). Nutrition of Fruit Trees. Mrs. Usha Raj Kumar for Kalyani publishers, New Delhi, p. 10 - 52 .

Pahla, I.; Tagwira, F.; Muzemu, S. and Chitamba, J. (2013). Effects of Soil Type and Manure Level on the Establishment and Growth of Moringa oleifera. International Journal of Agriculture and Forestry, 3(6):226-230.

Peixoto, R.; Silva, G.C.; Costa, R.A.; Joseí, L.S.; Vieira, G.H.F.; Filho, A.A.F. and Vieira H.S.F. (2011). In vitro antibacterial effect of aqueous and ethanolic Moringa leaf extracts. Asian Pacific J. Trop. Med., 4(3):201-204.

Pontual, V.E.; Belany, E.A.C.; Bezerra, S.R.; Coelho, C.B.; Napoleão, H.T. and Paiva, M.G.P. (2012). Caseinolytic and milkclotting activities from Moringa oleifera flowers. Food Chem., 135(3-1):18481854.

Ravikumar, S.; Ali, M. and Valliammal, N. (2011). Biofertilizer effect of halophilic Azospirillium on the growth of Jatropha curcas, L. seedlings. Ann. Biol. Res., 2(2):153-157.

Sakr, W.R.A.S. (2005). Effect of Organic and Biofertilization on Growth and Active Constituents Production of Senna Plants. Ph.D. Thesis, Fac. Agric., Cairo Univ., Egypt.

Spernat, M. (1990). Nitrogen Fixing Organisms, P.S. Chapman and Hall London.

Ugbaja, R.A.E. (1996). Growth and responses of castor oil plant to sources of organic manures in ferralitic soils. Agric. and Hort., 13(3):291-299.

Umar, A.F. (2014). Effect of Farm-Yard Manure and Inorganic Fertilizer Application on the Coppicing Ability of Moringa oleifera (Lam.) Plantation at Gaya, Kano, Nigeria. Umar, World J. Biol. Med. Science, 1(2):37-45. 


\section{استجابة المورنجا اوليفيرا للتسميا العضوي والحيوي والمعني النتروجيني الفوسفوري البوتاسي

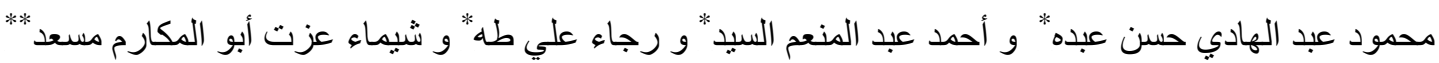

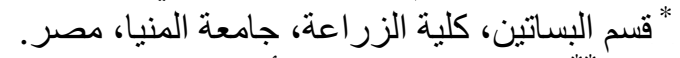

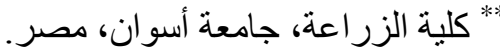

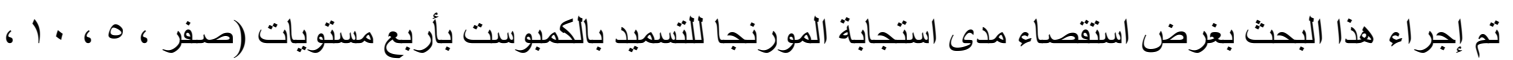

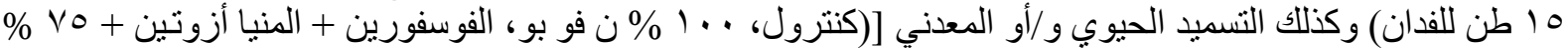

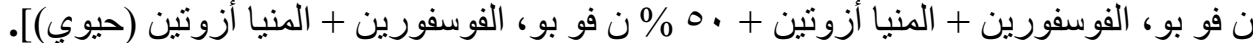

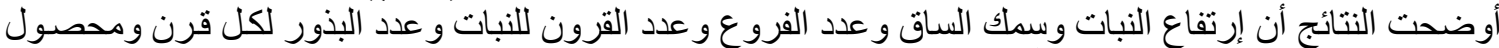

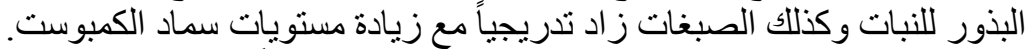

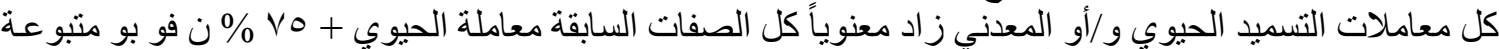

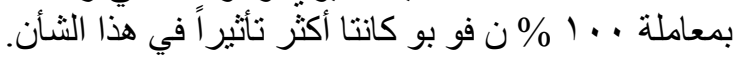

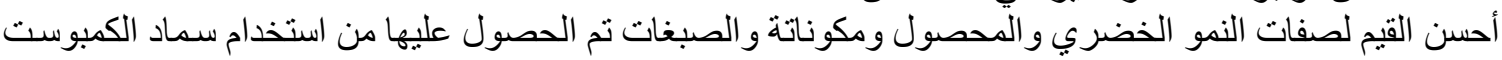
عند 10 طن للفدان مع خليط التسميد الحيوي + Vo \% من السماد المعدني. 
